\title{
Lactobacillus apodemi sp. nov., a tannase- producing species isolated from wild mouse faeces
}

\author{
Correspondence \\ Ro Osawa \\ osawa@ans.kobe-u.ac.jp
}

\author{
Ro Osawa, ${ }^{1}$ Tomohiko Fujisawa ${ }^{2}$ and Rüdiger Pukall ${ }^{3}$ \\ ${ }^{1}$ Department of Bioresources and Agrobiosciences, Graduate School of Science and \\ Technology, Kobe University, Rokko-dai 1-1, Nada-ku, Kobe, 657-8501, Japan \\ ${ }^{2}$ Department of Food Science and Technology, Nippon Veterinary and Animal Science \\ University, Kyonan-cho 1-7-1, Musashino-shi, Tokyo, 180-8602, Japan \\ ${ }^{3}$ DSMZ-Deutsche Sammlung von Mikroorganismen und Zellkulturen GmbH, Mascheroder Weg \\ 1b, D-38124 Braunschweig, Germany
}

\begin{abstract}
A Gram-positive, rod-shaped, non-endospore-forming bacterium, strain $\mathrm{ASB} 1^{\top}$, able to degrade tannin, was isolated from faeces of the Japanese large wood mouse, Apodemus speciosus. Comparative analysis of the 16S rRNA gene sequence revealed that the strain could be assigned as a member of the genus Lactobacillus. The nearest phylogenetic neighbours were determined as Lactobacillus animalis DSM $20602^{\top}$ (98.9\% 16S rRNA gene sequence similarity) and Lactobacillus murinus ASF 361 (98.9\%). Subsequent polyphasic analysis, including automated ribotyping and DNA-DNA hybridization experiments, confirmed that the isolate represents a novel species, for which the name Lactobacillus apodemi sp. nov. is proposed. The DNA G $+C$ content of the novel strain is $38.5 \mathrm{~mol} \%$. The cell-wall peptidoglycan is of type A4 $\alpha$ L-Lys-D-Asp. The type strain is $\mathrm{ASB}^{\top}{ }^{\top}$ (=DSM $16634^{\top}=$ CIP $108913^{\top}$ ).
\end{abstract}

In recent years, several studies have reported the presence of bacterial species with tannase activity in the guts or faeces of different animals (Osawa et al., 1995a, b). The Japanese large wood mouse (Apodemus speciosus) inhabits various types of forests in Japan. It feeds on acorns in autumn and winter which may contain considerable amounts of tannins (Sasaki et al., 2005). Fresh faecal pellets were collected from wild wood mice from the forests of Kyotanabe, Japan.

Bacterial strains were isolated from spread plates (tannic acid-treated brain heart infusion agar, prepared as described by Osawa, 1990) of serial diluted faecal samples incubated under anaerobic conditions at $37^{\circ} \mathrm{C}$. For further testing, the strains were grown in MRS medium (Difco). Colony and cell morphology were determined after 2 days of incubation. The ability to grow at 15 or $45^{\circ} \mathrm{C}$ was tested in MRS broth (Difco). Anaerobic growth was tested on MRS plates incubated using the Anaerocult A mini system (Merck). Catalase activity was determined by using reagent droppers (Becton Dickinson). Lactic acid configuration was determined using the D-lactic acid/L-lactic acid test kit (Boehringer Mannheim/R-Biopharm) based on the UV method, according to the manufacturer's instructions.

The GenBank/EMBL/DDBJ accession number for the 16S rRNA gene sequence of Lactobacillus apodemi sp. nov. DSM $16634^{\top}$ is AJ871178.
Phenotypic properties were determined using an API 50 CHL kit (bioMérieux).

Genomic DNA was extracted from bacterial cells and purified using a previously described protocol (Pukall et al., 1998). The primer pair $27 \mathrm{f}$ ( $5^{\prime}$-GAGTTTGATCCTGGCTCAG-3') and 1527r (5'-AGAAAGGAGGTGATCCAGCC-3') was used for amplification of the 16S rRNA gene (Lane, 1991). PCR amplification of the 16S rRNA-encoding gene was performed as described earlier (Pukall et al., 1999). Amplicons were sequenced by using the Dye-labelled Dideoxy Terminator cycle sequencing quick start kit and the CEQ 8000 Genetic Analysis System (both from Beckman Coulter). Sequences were manually aligned and compared with previously published sequences. These were stored in the Deutsche Sammlung von Mikroorganismen und Zellkulturen internal database consisting of more than 6000 16S rRNA gene sequence entries, including those from the Ribosomal Database Project (Maidak et al., 2001) and EMBL. Similarity values were transformed into genetic distance values that compensate for multiple substitutions at any given site in the sequence (Jukes \& Cantor, 1969). The neighbour-joining method contained in the PHYLIP package (Felsenstein, 1993) was used for the construction of a phylogenetic dendrogram. In addition, the DNAml algorithm for maximum-likelihood analysis (Felsenstein 1993) was applied, but revealed almost the same clusters for closely related species as shown in the neighbour-joining 
dendrogram. All analyses were done on a SUN SparcII workstation.

Automated ribotyping was carried out for strains $A S B 11^{\mathrm{T}}$ $\left(=\mathrm{DSM} 16634^{\mathrm{T}}\right)$, ASB2 (=DSM 16635), ASB6 (=DSM 16648), ASB8 (=DSM 16649) and ASB7 (=DSM 16748), that had been previously isolated from the faeces of Japanese large wood mice and found to be able to produce tannase (Sasaki et al., 2005). Fingerprints were generated by using the RiboPrinter microbial characterization system (Qualicon). The RiboPrinter system combines molecular processing steps for ribotyping in a stand-alone, automated instrument. Steps include cell lysis, digestion of chromosomal DNA with a restriction enzyme, separation of fragments by electrophoresis, transfer of DNA fragments to a nylon membrane, hybridization to an Escherichia coli $r r n \mathrm{~B}$ probe, chemiluminescent detection of the probe to the fragments containing rrn operon sequences, image detection and computerized analysis and storage of RiboPrint patterns. Sample preparation and analysis were performed according the manufacturer's instructions and the EcoRI restriction enzyme was used to generate restriction fragments. The band patterns were compared using BioNumerics software (Applied Maths). Clustering was performed by the UPGMA method based on the Pearson correlation coefficient using an optimization coefficient of $1 \cdot 2 \%$.

Analysis of the peptidoglycan structure was carried out as described by Schleifer (1985) and Schleifer \& Kandler (1972) with the modification that TLC on cellulose was applied instead of paper chromatography. Strain $A S B 1^{T}$ possesses cell-wall peptidoglycan of type A4 $\alpha$, L-Lys-D-Asp (type A11.31 according to the DSMZ catalogue of strains; DSMZ, 2001).

Estimation of the DNA G + C content of strain ASB1 ${ }^{\mathrm{T}}$ followed the procedure described by Sasaki et al. (2005). Levels of total DNA-DNA hybridization of genomic DNA extracted from the novel ASB strains and type strains of Lactobacillus animalis and Lactobacillus murinus were determined as described by Sasaki et al. (2005).

$16 \mathrm{~S}$ rRNA gene sequence analysis indicated that strain $\mathrm{ASB} 1^{\mathrm{T}}$ is a member of the genus Lactobacillus. L. murinus and $L$. animalis were determined to be the nearest phylogenetic neighbours to strain $\mathrm{ASB} 1^{\mathrm{T}}$, showing sequence similarity values of $98.9 \%$. The position of strain $\mathrm{ASB1}^{\mathrm{T}}$ relative to its phylogenetic neighbours is shown by neighbourjoining analysis (Fig. 1). In addition, a second algorithm, the maximum-likelihood method, included within the DNAml program (Felsenstein, 1993), was applied to confirm the phylogenetic position of strain $\mathrm{ASB1}^{\mathrm{T}}$. The most closely related species grouped together in both dendrograms. Strain $A S B 1^{\mathrm{T}}$ formed a stable cluster together with $L$. animalis and L. murinus. Both algorithms placed strain $\mathrm{ASB1}^{\mathrm{T}}$ near to the Lactobacillus mali group and the Lactobacillus salivarius group (Hammes \& Hertel, 2003). Partial sequences for all novel ASB strains tested revealed nearly identical stretches. Further, the close relationship of the novel ASB strains was confirmed by automated riboprinting (Fig. 2). The similarity of riboprint patterns obtained for the novel ASB strains, compared with strain $A S B 1^{T}$, ranged between $87 \cdot 5$ and $93.9 \%$. When compared

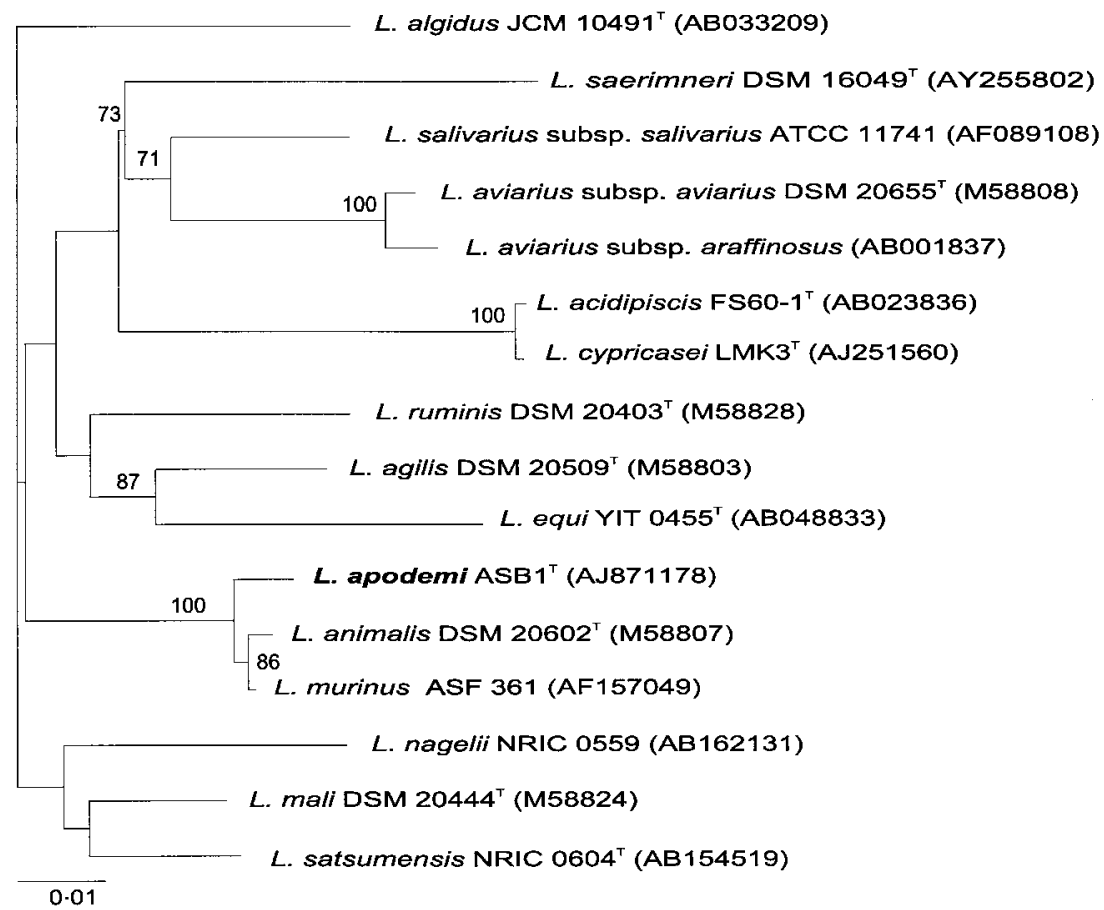

Fig. 1. Neighbour-joining tree showing the nearest phylogenetic neighbours for strain $\mathrm{ASB}^{\top}$. Bootstrap values (percentages of 1000 replications) with $>70 \%$ confidence are shown at branching points. Bar, 1 nucleotide substitution per 100 positions. 


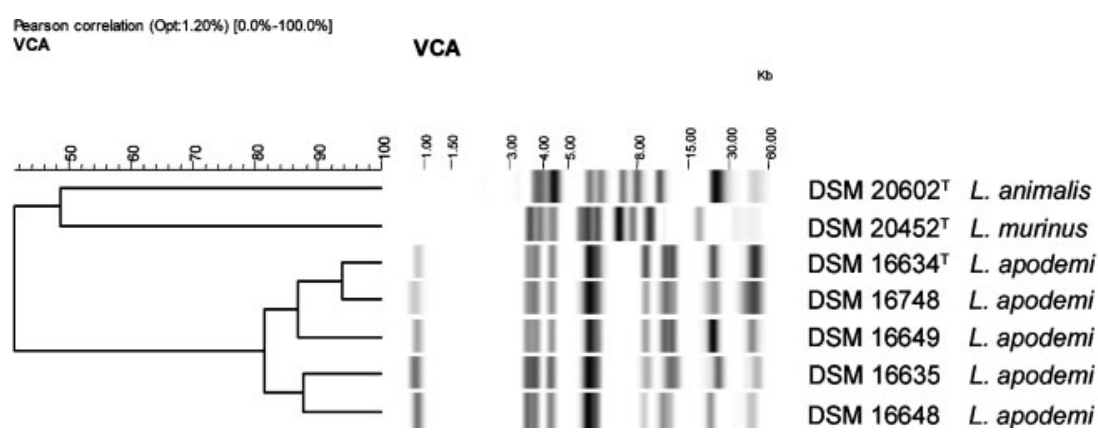

Fig. 2. Ribotype patterns obtained from ASB strains compared with those derived from L. animalis DSM $20602^{\top}$ and L. murinus DSM $20452^{\top}$. Cluster analysis was performed by UPGMA based on the Pearson correlation coefficient using an optimization coefficient of $1 \cdot 2$. VCA indicates a standard EcoRI batch.

with strain $A S B 1^{\mathrm{T}}$, the similarity values of fingerprints derived from L. animalis DSM $20602^{\mathrm{T}}$ and L. murinus DSM $20452^{\mathrm{T}}$ were determined to be low $(<50 \%)$.

Finally, DNA-DNA hybridization experiments performed previously (Sasaki et al., 2005) showed that all the ASB strains tested could be representatives of the same species, with a relative DNA-DNA hybridization with strain $A S B 1^{\mathrm{T}}$ of between $73 \cdot 8$ and $97 \cdot 3 \%$. In contrast, relative binding of DNA from strain $\mathrm{ASB}^{\mathrm{T}}$ with the type strains of $L$. animalis and L. murinus gave values of $<15 \%$ (Sasaki et al., 2005).

Phenotypic properties differentiating strain $\mathrm{ASB}^{\mathrm{T}}$ from the type strains of L. animalis and L. murinus are summarized in Table 1.

The above evidence and the phenotypic characteristics described previously (Sasaki et al., 2005) and summarized within the species description confirm that the ASB strains represent a novel species, for which the name Lactobacillus apodemi sp. nov. is proposed. The type strain is $\mathrm{ASB}^{\mathrm{T}}$ $\left(=\right.$ DSM $16634^{\mathrm{T}}=$ CIP $\left.108913^{\mathrm{T}}\right)$.

\section{Description of Lactobacillus apodemi sp. nov.}

Lactobacillus apodemi (a'po.de.mi. N.L. gen. n. apodemi of Apodemus, the genus name of the field mouse, Apodemus speciosus, from which the organism was first isolated).

Gram-positive, non-motile, non-endospore-forming, catalase-negative rods, $0 \cdot 5-1 \times 5-6 \mu \mathrm{m}$ in size and occurring as single cells or in pairs. After anaerobic growth at $37^{\circ} \mathrm{C}$ for $48 \mathrm{~h}$, colonies on MRS agar are 2-3 $\mathrm{mm}$ in diameter. Colonies are white with an opaque border, smooth and convex. Growth on MRS agar also occurs under microaerophilic conditions and reduced growth is detected under aerobic conditions. Best growth occurs at temperatures between 25 and $37^{\circ} \mathrm{C}$. In MRS broth, growth occurs at $45^{\circ} \mathrm{C}$, but not at $15^{\circ} \mathrm{C}$. Produces gallic acid from tannic acid (tannase-positive), but does not convert gallic acid further to pyrogallol (Sasaki et al., 2005). Only L-lactate is produced. Gas is not produced from glucose as tested in MRS broth with a Durham tube. Acid is produced from galactose, D-glucose, D-fructose, D-mannose, $N$-acetylglucosamine, arbutin, maltose, lactose, melibiose, sucrose, trehalose and D-raffinose. Acid is not produced from glycerol, erythritol, D-arabinose, L-arabinose, D-xylose, L-xylose, adonitol, methyl D-xyloside, L-sorbose, rhamnose, dulcitol, inositol, mannitol, sorbitol, methyl D-mannoside, methyl Dglucoside, amygdalin, inulin, melezitose, starch, glycogen, xylitol, $\beta$-gentiobiose, D-turanose, D-lyxose, D-tagatose, D-fucose, L-fucose, D-arabitol, L-arabitol, gluconate, 2ketogluconate or 5-ketogluconate. Ribose, salicin and cellobiose are variable. Aesculin is hydrolysed. The DNA $\mathrm{G}+\mathrm{C}$ content of the type strain is $38.5 \mathrm{~mol} \%$ and the cell-wall peptidoglycan is of type A $4 \alpha$, L-Lys-D-Asp (type A11.31).

The type strain, $\mathrm{ASB}^{\mathrm{T}}\left(=\mathrm{DSM} 16634^{\mathrm{T}}=\mathrm{CIP} 108913^{\mathrm{T}}\right.$ ), was isolated from faeces of the Japanese large wood mouse, Apodemus speciosus.

Table 1. Comparison of phenotypic properties of $L$. apodemi sp. nov. $A S B 1^{\top}$ and its nearest phylogenetic neighbours

\begin{tabular}{|lcccc|}
\hline Characteristic & L. apodemi ASB1 & L. animalis $\mathrm{JCM}$ & $\mathbf{5 6 7 0}$ & L. murinus $\mathrm{JCM}^{\mathrm{T}} \mathbf{1 7 1 7}^{\mathrm{T}}$ \\
\hline Tannase activity & + & - & - \\
Utilization of: & - & - & + \\
Mannitol & + & - & - \\
Trehalose & - & - & + \\
Gentiobiose & & & \\
\hline
\end{tabular}




\section{References}

DSMZ (2001). Catalogue of Strains, 7th edn, p. 617. Braunschweig: DSMZ. http://www.dsmz.de/species/murein.htm

Felsenstein, J. (1993). PHYLIP - Phylogenetic inference package, version 3.5.1. Distributed by the author. Department of Genome Sciences, University of Washington, Seattle, USA.

Hammes, W. P. \& Hertel, C. (2003). The genera Lactobacillus and Carnobacterium. In The Prokaryotes: an Evolving Electronic Resource for the Microbiological Community, release 3.15. Edited by M. Dworkin, S. Falkow, E. Rosenberg, K. H. Schleifer \& E. Stackebrandt. New York: Springer. http://link.springer-ny.com/link/service/books/10125/

Jukes, T. H. \& Cantor, C. R. (1969). Evolution of protein molecules. In Mammalian Protein Metabolism, pp. 21-132. Edited by H. N. Munro. New York: Academic Press.

Lane, D. J. (1991). 16S-23S rRNA sequencing. In Nucleic Acid Techniques in Bacterial Systematics, pp. 125-175. Edited by E. Stackebrandt \& M. Goodfellow. Chichester: Wiley.

Maidak, B. L., Cole, J. R., Lilburn, T. G. \& 7 other authors (2001). The RDP-II (Ribosomal Database Project). Nucleic Acids Res 29, 173-174.

Osawa, R. (1990). Formation of a clear zone on tannin-treated brain heart infusion agar by Streptococcus sp. isolated from feces of koalas. Appl Environ Microbiol 56, 829-831.
Osawa, R., Fujisawa, T. \& Sly, L. I. (1995a). Streptococcus gallolyticus sp. nov.; gallate degrading organisms formerly assigned to Streptococcus bovis. Syst Appl Microbiol 18, 74-78.

Osawa, R., Rainey, F., Fukisawa, T., Lang, E., Busse, H. J., Walsh, T. P. \& Stackebrandt, E. (1995b). Lonepinella koalarum gen. nov., sp. nov., a new tannin-protein complex degrading bacterium. Syst Appl Microbiol 18, 368-373.

Pukall, R., Brambilla, E. \& Stackebrandt, E. (1998). Automated fragment length analysis of fluorescently-labeled 16S rDNA after digestion with 4-base cutting restriction enzymes. J Microbiol Methods 32, 55-63.

Pukall, R., Buntefuss, D., Fruhling, A., Rohde, M., Kroppenstedt, R. M., Burghardt, J., Lebaron, P., Bernard, L. \& Stackebrandt, E. (1999). Sulfitobacter mediterraneus sp. nov., a new sulfite-oxidizing member of the $\alpha$-Proteobacteria. Int J Syst Bacteriol 49, 513-519.

Sasaki, E., Shimada, T., Osawa, R., Nishitani, Y., Spring, S. \& Lang, E. (2005). Isolation of tannin-degrading bacteria isolated from feces of the Japanese large wood mouse, Apodemus speciosus, feeding on tannin-rich acorns. Syst Appl Microbiol 28, 358-365.

Schleifer, K. H. (1985). Analysis of the chemical composition and primary structure of murein. Methods Microbiol 18, 123-156.

Schleifer, K. H. \& Kandler, O. (1972). Peptidoglycan types of bacterial cell walls and their taxonomic implications. Bacteriol Rev 36, 407-477. 